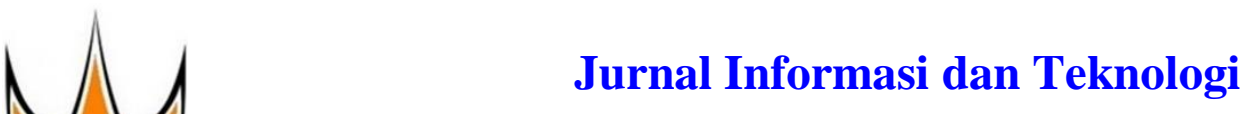

http://www.jidt.org

2021 Vol. 3 No. $4 \quad$ Hal: $245-250$

e-ISSN: 2714-9730

\title{
Prediksi Tingkat Prevalensi Stunting Kabupaten Lima Puluh Kota Menggunakan Metode Monte Carlo
}

\author{
Mike Zaimy ${ }^{1 \bowtie}$, Sarjon Defit ${ }^{2}$, Gunadi Widi Nurcahyo ${ }^{3}$ \\ ${ }^{123}$ Universitas Putra Indonesia YPTK Padang \\ mikezaimy@gmai1.com
}

\begin{abstract}
Stunting is a condition of failure to thrive in children under five years old (infants under five years old) due to chronic malnutrition so that children are too short for their age. According to available data, the stunting prevalence rate in Lima Puluh Kota Regency in 2020 is quite high, at $8.28 \%$. This has become the attention of the central government by establishing Lima Puluh Kota Regency as one of the Regencies/Cities Locations for the National Integrated Stunting Reduction Intervention Focus. The results of this study aim to assist the District Government of Lima Puluh Kota in planning the convergence of programs/interventions as an effort to accelerate stunting prevention and reduce the percentage of stunting under five in Lima Puluh Kota Regency. This research data uses the stunting prevalence rate from 2018 to 2020 which comes from data on the number of toddlers and the number of stunting toddlers from 22 health centers in Lima Puluh Kota Regency. Furthermore, the data was processed using the Monte Carlo method to predict the stunting prevalence rate in 2021. Based on the tests conducted using the Monte Carlo method, the highest stunting prediction rates were found at the Pakan Rabaa Public Health Center and the Suliki Public Health Center with a stunting prevalence rate of $11.70 \%$. The level of accuracy obtained is $93.73 \%$. The Monte Carlo method is suitable for predicting the prevalence of stunting in Lima Puluh Kota Regency, seen from the high level of accuracy from the results of data processing.
\end{abstract}

Keywords: Simulation, Model, Monte Carlo, Prediction, Prevalence, Stunting

\begin{abstract}
Abstrak
Stunting merupakan kondisi gagal tumbuh pada anak balita (bayi di bawah lima tahun) akibat dari kekurangan gizi kronis sehingga anak terlalu pendek untuk usianya. Menurut data yang ada, angka prevalensi stunting di Kabupaten Lima Puluh Kota tahun 2020 cukup tinggi yakni sebesar $8,28 \%$. Hal ini menjadi perhatian pemerintah pusat dengan menetapkan Kabupaten Lima Puluh Kota sebagai salah satu Kabupaten/Kota Lokasi Fokus Intervensi Penurunan Stunting Terintegrasi Secara Nasional. Hasil penelitian ini bertujuan untuk membantu Pemerintah Kabupaten Lima Puluh Kota dalam perencanaan konvergensi program/intervensi sebagai salah satu upaya percepatan pencegahan stunting dan menurunkan persentase balita stunting di Kabupaten Lima Puluh Kota. Data penelitian ini menggunakan angka prevalensi stunting dari tahun 2018 sampai tahun 2020 yang berasal dari data jumlah balita dan jumlah balita stunting dari 22 puskesmas yang berada di Kabupaten Lima Puluh Kota. Selanjutnya data tersebut diolah menggunakan metode Monte Carlo untuk memprediksi tingkat prevalensi stunting tahun 2021. Berdasarkan pengujian yang dilakukan menggunakan metode Monte Carlo, didapatkan hasil tingkat prediksi stunting yang tertinggi berada pada puskesmas Pakan Rabaa dan puskesmas Suliki dengan angka prevalensi stunting sebesar $11,70 \%$. Adapun tingkat akurasi yang diperoleh sebesar 93,73\%. Metode Monte Carlo cocok digunakan untuk prediksi angka prevalensi stunting di Kabupaten Lima Puluh Kota dilihat dari tingkat akurasinya yang cukup tinggi dari hasil pengolahan data.
\end{abstract}

Kata kunci: Simulasi, Model, Monte Carlo, Prediksi, Prevalensi, Stunting

(C) 2021 JIdT

\section{Pendahuluan}

Stunting merupakan salah satu bentuk dari adanya gangguan pertumbuhan pada tubuh. Bila ini terjadi, maka salah satu organ tubuh yang cepat mengalami risiko adalah otak. Dalam otak terdapat sel syaraf yang sangat berkaitan dengan respon anak termasuk dalam melihat, mendengar, dan berpikir selama proses belajar [1]. Stunting terjadi ketika seorang bayi tidak tumbuh secara optimal akibat kurangnya asupan gizi pada 1000 hari pertama kehidupannya yang tidak terjaga. Stunting dapat menimbulkan beberapa dampak yang buruk, baik dalam jangka pendek maupun dalam jangka panjang. Pada jangka pendek stunting dapat menyebabkan efek Simulasi adalah suatu metode yang digunakan untuk gagal tumbuh, terhambatnya perkembangan kognitif mengeksekusi perilaku dan model dalam perangkat dan motorik sehingga berpengaruh pada perkembangan otak dan keberhasilan pendidikan, dan tidak optimalnya ukuran fisik tubuh serta gangguan metabolisme pada anak. Sedangkan, dampak jangka panjang yang ditimbulkan stunting adalah menurunnya kapasitas intelektual, gangguan struktur dan fungsi syaraf dan sel-sel otak yang bersifat permanen dan menyebabkan penurunan kemampuan memahami pelajaran di usia sekolah yang berpengaruh pada produktivitas saat dewasa, serta meningkatkan resiko penyakit tidak menular seperti diabetes, hipertensi, jantung koroner dan stroke [2].

Diterima: 29-08-2021 | Revisi: 01-10-2021 | Diterbitkan: 31-12-2021| doi: 10.37034/jidt.v3i4.165 
lunak [3]. Model simulasi biasanya memperhitungkan Selain itu metode Monte Carlo juga dapat dimanfaatkan keadaan sistem yang ditangkap melalui nilai - nilai dalam meningkatkan kinerja pelayanan, dan variabel yang telah ditetapkan [4]. Simulasi sering mengurangi waktu tunggu konsumen sehingga digunakan dalam mempelajari atau menganalisis pelayanan yang diberikan petugas kepada konsumen perilaku kerja dari suatu sistem atau proses oleh yang dapat memberikan kepuasan tersendiri [13]. manajemen dalam menyelesaikan pekerjaannya [5]. Dalam dunia bisnis simulasi Monte Carlo dapat Sehingga dapat disimpulkan bahwa simulasi digunakan sebagai sebuah aplikasi pembantu pimpinan merupakan program (software) komputer yang perusahaan untuk mengambil strategi bisnis dengan berfungsi untuk meniru perilaku sistem nyata.

Tugas yang paling dasar dari sebuah simulasi Monte Carlo adalah menghasilkan satu set poin yang cepat dan optimal [14].ditambah lagi metode ini dapat membantu dalam memprediksi pendapatan pemerintah dalam pengelolan pajak [15].

didistribusikan sesuai dengan fungsi distribusi Tidak sampai disitu simulasi Monte Carlo juga probabilitas yang diketahui pada ruang fase target yang membantu dalam kegiatan pengadaan [16] dan akan dicari [6]. Prediksi bisa dikatakan sebagai sebuah perencanaan penganggaran [17]. Pada kegiatan model yang sensitif terhadap jumlah parameter input penetapan penggunaan pestisida simulasi ini juga dapat yang kompleks dan sering digabungkan. Beberapa di di gunakan [18]. Monte Carlo juga berhasil antara parameter tersebut memiliki rentang nilai yang mengeksploitasi dengan estimasi probabilitas dapat diterima dari literatur dan oleh karena itu kegagalan kecil dalam praktik teknik dengan memilih nilai yang sesuai merupakan sebuah pekerjaan memperkirakan indeks Sobol dengan biaya komputasi yang tidak mudah [7]. Simulasi Monte Carlo ini yang rendah dengan mengembangkan Aplikasi dengan dibangun berdasarkan pada penggunaan angka-angka strategi mentransformasikan evaluasi integral menjadi yang bersifat random untuk mengidentifikasi sebuah masalah inferensi Bayesian. Sehingga efisiensi dari permasalahan [8]. Istilah Monte Carlo sering dianggap metode yang baru dikembangkan ini sangat tinggi [19]. sama dengan simulasi probabilistik, hal ini dikarenakan simulasi Monte Carlo terbukti dapat memprediksi apa yang akan terjadi di masa yang akan datang [9].

Simulasi Monte Carlo dapat menjadi jawaban atas permasalahan ketidakpastian dalam pekerjaan. Banyak keuntungan dalam penggunaana simulasi ini Adapun yang melatarbelakangi penelitian ini adalah diantaranya simulasi ini merupakan sebuah perangkat karena tingginya tingkat prevalensi stunting di yang cermat dalam menganalisa kemungkinan Kabupaten Lima Puluh Kota yang menyebabkan ketidakpastian yang sering terjadi dalam berbagai ditetapkan sebagai salah satu lokasi focus penanganan macam bentuk pekerjaan. Dengan adanya keuntungan stunting nasional oleh Badan Perencana Pembangunan tersebut, diharapkan meminimalisir risiko Nasional Tahun 2020 [10]. Penelitian ini diharapkan ketidakpastian dan pekerjaan dapat berjalan dengan dapat membantu Pemerintah Kabupaten Lima Puluh optimal baik di sisi waktu, sumber daya, maupun biaya. Kota dalam menangani masalah stunting dengan Namun dalam praktiknya banyak yang menganggap melakukan prediksi tingkat prevalensi stunting tahun metode ini sebagai beban karena kurangnya 2021. Selain itu, mengetahui Bagaimana menerapkan pemahaman terhadap statistika dan metode Monte metode Monte Carlo untuk prediksi tingkat prevalensi Carlo tersebut [20].

stunting di Kabupaten Lima Puluh Kota dan Bagaimana cara menerapkan metode Monte Carlo ke dalam bahasa pemrograman PHP untuk memprediksi tingkat prevalensi stunting di Kabupaten Lima Puluh Kota.

Banyak penelitan yang telah berhasil menerapkan metode Monte Carlo dalam melakukan prediksi diantaranya dengan simulasi Monte Carlo menguji pengaruh pandemic COVID19 terhadap volatilitas pengembalian minyak, yang berhasil menyimpulkan

\section{Metodologi Penelitian}

Dalam menyelesaikan masalah yang diangkat pada penelitian ini yaitu prediksi tingkat prevalensi stunting di Kabupaten Lima Puluh Kota maka disusun kerangka kerja yang membantu kelancaran pelaksanaan penelitian ini menjadi lebih terukur dan terarah. Adapun bentuk kerangka kerja yang dilakukan disajikan pada Gambar 1. bahwa selama krisis virus corona terdapat fakta bahwa terjadi penurunan volatilitas harga minyak yang merupakan akibat dari krisis covid-19 [11]. Di Uni Emirat Arab Simulasi Monte Carlo, juga digunakan untuk mengoperasionalkan proses baru dalam memprioritaskan risiko proyek sehingga dapat dilakukan penanganan dini terhadap resiko yang berdampak besar yang dilakukan dengan menggunakan data matriks risiko [12]. 


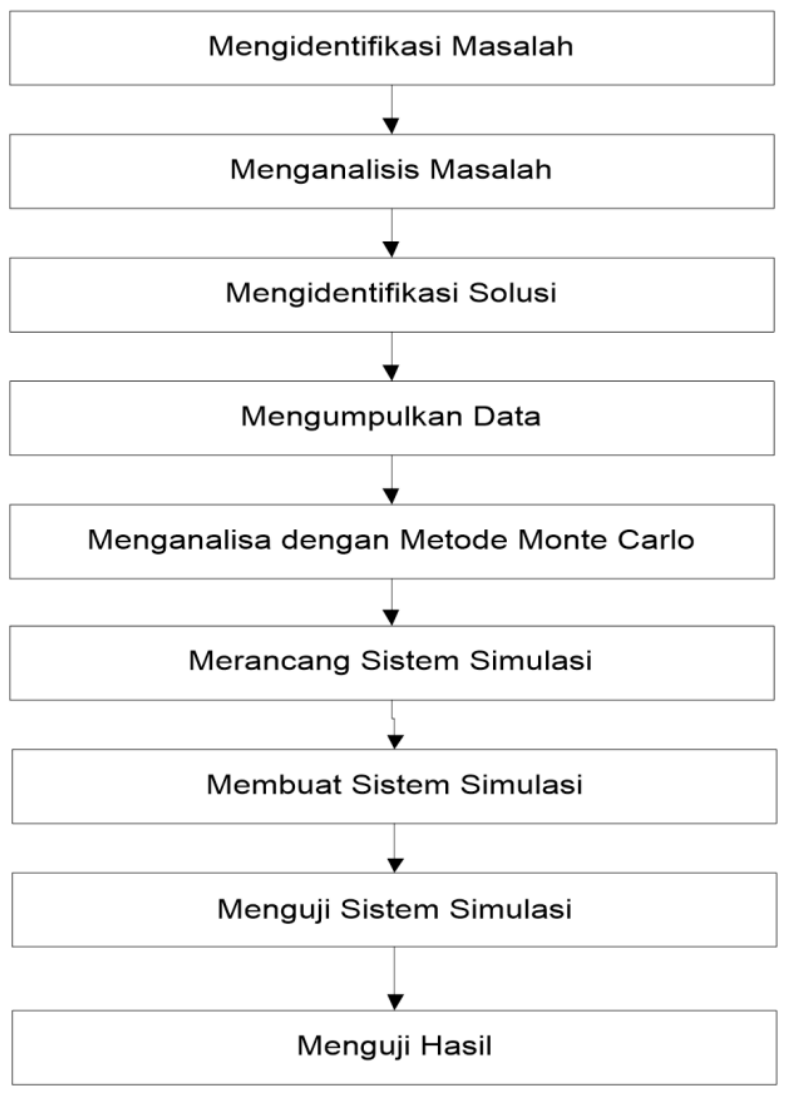

Gambar 1. Kerangka kerja penelitian yang dipelajari tersebut, diseleksi untuk dapat ditentukan solusi-solusi mana yang akan digunakan dalam penelitian. Solusi diambil dari internet, yang berupa artikel dan jurnal ilmuah tentang Monte Carlo serta bahan bacaan lain yang mendukung penelitian.

\subsection{Mengumpulkan Data-data}

Pengumpulan data dilakukan dengan mengumpulkan data jumlah balita dan jumlah balita stunting yang pada Puskesmas di Kabupaten Lima Puluh Kota. Di mana data tersebut dapat ditemukan pada Dinas Kesehatan Kabupaten Lima Puluh Kota. Dalam mengumpulkan data dilakukan observasi yaitu pengamatan secara langsung ditempat penelitian sehingga permasalahan yang ada dapat diketahui secara jelas dan tepat. Data yang akan dipakai untuk penelitian adalah data jumlah balita dan jumlah balita stunting tahun 2018, 2019, dan 2020.

\subsection{Menganalisa dengan Metode Monte Carlo}

Pada tahapan ini dilakukan dilakukan pengamatan pada setiap variabel yang digunakan untuk selanjutnya dilakukan perhitungan menggunakan metode Monte Carlo. Sehingga kemudian hasil dari perhitungan menggunakan variabel yang selanjutnya dilakukan perbandingan dengan data-data yang telah diperoleh. Sebagai alat bantu dalam melakukan perhitungan Monte Carlo ini dapat menggunakan Microsoft Excell. Hal ini dilakukan untuk meminimalisir dampak Setelah menetapkan kerangka kerja yang akan kesalahan menggunakan perhitungan manual. dilakukan, untuk keterangan petunjuk kerja lebih rinci dapat dijelaskan sebagai berikut :

\subsection{Mengidentifikasi Masalah} Ta merupakan langkah awal untuk representasi data dan struktur program, karakteristikmempersiapkan penelitian yaitu mengidentifikasi karakteristik antar muka, dan rincian prosedural yang masalah, karena tanpa adanya suatu permasalahan diikhtisarkan dari hal-hal yang berkaitan dengan maka tidak akan pernah didapat solusi yang tepat dari kebutuhan-kebutuhan informasi. Dalam merancang permasalahan tersebut. Pada tahapan ini peneliti juga suatu sistem simulasi perlu diperhatikan tentang model mencari sumber literatur dan data awal yang bertujuan konseptual di mana model konseptual menunjukkan agar penelitian ini menjadi lebih terarah dan tujuan dari keterkaitan antar variabel yang menentukan perilaku penelitian ini dapat tercapai.

\subsection{Menganalisis Masalah} sistem. Model konseptual ini yang akan menjadi suatu kerangka dalam membentuk performansi yang akan dicapai. Sehingga pada akhirnya, pada perancangan ini Pada tahapan menganalisis masalah dilakukan untuk logika dari Monte Carlo akan dituangkan dalam bentuk memahami masalah yang ada, ruang lingkup dan aplikasi. Adapun aplikasi yang dibangun akan batasan masalahnya. Dengan dilakukannya analisa menggunakan bahasa pemrograman PHP dengan masalah diharapkan akan mendapatkan solusi yang database manajemen MySQL. tepat terhadap permasalahan yang diangkat dalam penelitian ini. Pada tahapan ini dimulai proses memprediksi jumlah balita dan angka stunting yang akan datang melalui data yang diperoleh dari puskesmas yang ada di Kabupaten Lima Puluh Kota.

\subsection{Mengidentifikasi Solusi}

\subsection{Membuat Sistem Simulasi}

Pada tahapan ini suatu rancangan aplikasi yang telah dibuat akan dituangkan ke dalam sebuah pemrograman sistem informasi prediksi stunting berbasis web menggunakan PHP. Aplikasi yang akan dibangun bertujuan untuk mempermudah user untuk Untuk mencapai target yang diharapkan, maka mendapatkan suatu pengetahuan (Knowladge Base) dipelajari beberapa solusi-solusi yang mungkin terkait tingkat prevalensi stunting di Kabupaten Lima bermanfaat untuk kedepannya. Kemudian solusi-solusi Puluh Kota.

Jurnal Informasi dan Teknologi Vol. 3 No. 4 (2021) 245-250 


\subsection{Menguji Sistem Simulasi}

Pada tahapan ini akan dilakukan pengujian terhadap aplikasi yang dibangun. Di mana akan diuji perbandingan hasil dari simulasi Monte Carlo yang dilakukan secara manual, lalu dibandingkan dengan hasil dari simulasi Monte Carlo yang dilakukan menggunakan aplikasi. Perbandingan antara model dan Penelitian dilakukan dengan terlebih dahulu sistem nyata merupakan perbandingan statistik dan memprediksi jumlah balita tiap tahunnya pada 22 perbedaan dalam performans harus diuji untuk puskesmas yang tersebar di Kabupaten Lima Puluh signifikansi statistiknya. Perbandingan ini tidak bisa Kota dan dilanjutkan dengan memprediksi jumlah dilakukan dengan sederhana, karena performans yang balita stunting untuk tiap-tiap tahunnya untuk semua diukur menggunakan simulasi didasarkan pada periode puskesmas. Setelah didapatkan hasil prediksi jumlah waktu yang sangat lama, mungkin beberapa tahun.

\subsection{Menguji Hasil}

Pada tahapan ini penulis melakukan pengujian terhadap sistem yang telah dirancang sebelumnya, adapun mekanisme pengujian pada tahap ini adalah sebagai berikut:

a. Pengumpulan data jumlah balita dan balita stunting tahun 2018 sampai dengan tahun 2020.

b. Melakukan analisa tingkat prevalensi stunting menggunakan metode Monte Carlo sesuai dengan data yang diperoleh. c. Melakukan analisa dan simulasi tingkat prevalensi stunting dengan menggunakan sistem informasi yang dibangun.

d. Melakukan perbandingan hasil.

balita dan jumlah balita stunting maka dilanjutkan dengan melakukan perhitungan tingkat prevalensi stunting dari hasil simulasi yang diperoleh, Dari rangkaian simulasi yang dilakukan diperoleh hasil sebagai berikut :

3.1 Pada tahapan pengolahan data maka didapatkan data awal seperti Tabel 1, yang didapatkan dari proses wawancara dan observasi dengan Dinas Kesehatan Kabupaten Lima Puluh Kota.

Tabel 1. Data di Puskesmas se-Kabupaten Lima Puluh Kota (orang)

\begin{tabular}{lrrrrrrrrr}
\hline \multirow{2}{*}{ PUSKESMAS } & \multicolumn{2}{c}{2018} & & \multicolumn{2}{c}{2019} & \multicolumn{3}{c}{2020} \\
\cline { 2 - 13 } & Balita & Stunting & $\%$ & Balita & Stunting & $\%$ & Balita & Stunting & $\%$ \\
\hline Padang Kandis & 676 & 24 & 3,6 & 571 & 19 & 3,3 & 481 & 10 & 5,0 \\
\hline Rimbo Data & 376 & 50 & 13,3 & 323 & 44 & 13,6 & 349 & 40 & 11,5 \\
\hline Dangung-dangung & 1.722 & 43 & 2,5 & 1.542 & 73 & 4,7 & 1478 & 83 & 8,5 \\
\hline Baruah Gunuang & 429 & 64 & 14,9 & 430 & 78 & 18,1 & 435 & 66 & 15,2 \\
\hline Maek & 669 & 62 & 9,3 & 664 & 98 & 14,8 & 639 & 57 & 9,1 \\
\hline Banja Laweh & 395 & 113 & 28,6 & 386 & 58 & 15,0 & 410 & 46 & 11,2 \\
\hline Gunung Malintang & 515 & 82 & 15,9 & 468 & 91 & 19,4 & 453 & 53 & 11,7 \\
\hline Sialang & 793 & 127 & 16,0 & 780 & 76 & 9,7 & 829 & 66 & 8,0 \\
\hline Piladang & 835 & 175 & 21,0 & 580 & 49 & 8,4 & 659 & 34 & 5,4 \\
\hline Halaban & 1.068 & 128 & 12,0 & 1.025 & 91 & 8,9 & 999 & 60 & 6,1 \\
\hline Mungka & 1.999 & 111 & 5,6 & 1.617 & 95 & 5,9 & 1.691 & 100 & 6,3 \\
\hline Pakan Rabaa & 1597 & 90 & 5,6 & 1.429 & 149 & 10,4 & 1.426 & 106 & 8,1 \\
\hline Suliki & 901 & 126 & 14,0 & 865 & 136 & 15,7 & 782 & 84 & 10,9 \\
\hline Muaro Paiti & 838 & 123 & 14,7 & 1.279 & 164 & 12,8 & 1.072 & 96 & 10,3 \\
\hline Koto Baru & 1.996 & 31 & 1,6 & 2.458 & 223 & 9,1 & 2.186 & 199 & 9,3 \\
\hline Batu Hampar & 1.100 & 219 & 19,9 & 1.065 & 103 & 9,7 & 974 & 94 & 9,9 \\
\hline Taram & 1.369 & 244 & 17,8 & 1.063 & 111 & 10,4 & 1.208 & 52 & 4,3 \\
\hline Koto tinggi & 874 & 199 & 22,8 & 820 & 204 & 24,9 & 841 & 130 & 15,7 \\
\hline Situjuah & 1.687 & 228 & 13,5 & 1.521 & 178 & 11,7 & 1.387 & 153 & 11,6 \\
\hline Mungo & 2.088 & 247 & 11,8 & 1.782 & 214 & 12,0 & 1.718 & 116 & 7,3 \\
\hline Pangkalan & 1.352 & 285 & 21,1 & 1.277 & 198 & 15,5 & 1.235 & 195 & 15,8 \\
\hline Tanjung pati & 2.725 & 422 & 15,5 & 2.297 & 189 & 8,2 & 2.512 & 131 & 8,1 \\
\hline Jumlah & 26.004 & 3.193 & 12,3 & 24.242 & 2.641 & 10,9 & 23.764 & 1.971 & 8,3 \\
\hline
\end{tabular}

3.2 Selanjutnya dilakukan analisa tingkat prevalensi stunting dengan menerapkan metode Monte Carlo sesuai dengan data yang diperoleh, dimana tingkat prevalensi menggunakan PErsamaan (1).

$$
P=\frac{B}{S} \times 100 \%
$$

Dimana, $\mathrm{P}$ merupakan tingkat prevalensi stunting yang diperoleh dari hasil pembagian dari B yang merupakan jumlah balita dengan $\mathrm{S}$ yaitu jumlah balita stunting.
Dalam penerapan simulasi meenggunakan metode Monte Carlo terpadat beberapa rangkaian kegiatan yang dilakukan untuk mendapatkan hasil prediksi yang akurat. Rangkaian kegiatan dimaksud adalah:

a. Menghitung nilai probabilitas data jumlah balita dan jumlah balita stunting

b. Menghitung nilai distribusi probabilitas kumulatif untuk data jumlah balita dan jumlah balita stunting berdasarkan nilai distribusi probabilitas yang didapatkan sebelumnya. Di mana dalam 
menentukan nilai distribusi probabilitas kumulatif dapat diperoleh dengan Rumus (2).

$$
D p k e_{-i}=\frac{\mathrm{Jf} \mathrm{ke}-\mathrm{i}}{\mathrm{Tf}(\mathrm{n})}
$$

Di mana : Dp ke-i, Distribusi Probabilitas ke-i, Jf $k e-i$,jumlah Frekuensi $\mathrm{Ke}-\mathrm{i}$, dan $T f(n)$ merupakan total frekuensi (n).

c. Menentukan interval angka acak untuk data jumlah balita dan jumlah balita stunting yang dibuat berdasarkan nilai probabilitas kumulatif yang didapat pada tahapan sebelumnya. Dapat dijelaskan bahwa untuk menentukan nilai interval acak sama dengan cara sebelumnya yaitu dengan menetapkan nilai awal sama dengan 1 dan nilai akhir dengan cara nilai pada probabilitas komulatif frekuensi pertama dikali dengan 100 .

d. Perhitungan membangkitkan bilangan acak data jumlah balita dan jumlah balita stunting data jumlah balita dan jumlah balita stunting. Pada tahapan ini dilakukan pembangkitan angka acak dengan menggunakan Persamaan (3) dan (4).

$$
\begin{gathered}
Z_{i}+1=a Z_{i}+\mathrm{c} \\
\mathrm{Z}_{\mathrm{i}}+1=\left(\mathrm{aZ} \mathrm{Z}_{\mathrm{i}}+\mathrm{c}\right) \bmod \mathrm{M}
\end{gathered}
$$

Di mana, $Z i$ Angka pertama yang bebas ditentukan, a Angka pertama yang bebas ditentukan sendiri, $c$ Angka bebas tetapi tidak ada hubungan dengan m, Mod Modulus, $M$ Bilangan Tetap. Hasil penelitian tentang tahapan pembangkitan bilangan acak yang telah dilakukan oleh peneliti, persamaan diatas memiliki ketentuan nilai dengan menggunakan bilangan prima

Adapun hasil perhitungan yang dapat dilakukan untuk membangkitkan bilangan acak jumlah balita dan jumlah balita stuntin untuk tiap tahunnya, menggunakan parameter-parameter dengan nilai a $=8, \mathrm{c}=48, \mathrm{~m}=35, \mathrm{Zi}=93$. Selanjutnya, parameter-parameter tersebut digunakan untuk membangkitkan bilangan acak.

e. Melakukan Percobaan Simulasi Prediksi, merupakan percobaan simulasi prediksi ini dilakukan agar hasil dari percobaan simulasi prediksi data tahun sebelumnya yang menggunakan nilai angka acak dapat digunakan untuk membandingkan jumlah balita stunting dan balita stunting pada di tahun berikutnya.

Dari rangkaian perhitungan manual metode Monte Carlo yang dilakukan maka didapatkan hasil yang

\begin{tabular}{|c|c|c|c|c|c|c|c|c|c|c|}
\hline \multirow{2}{*}{ NO } & \multirow{2}{*}{ PUSKESMAS } & \multicolumn{3}{|c|}{2019} & \multicolumn{3}{|c|}{2020} & \multicolumn{3}{|c|}{2021} \\
\hline & & Balita & Stunting & $\%$ & Balita & Stunting & $\%$ & Balita & Stunting & $\%$ \\
\hline 1 & Padang Kandis & 835 & 175 & 21,0 & 580 & 49 & 8,45 & 659 & 34 & 5,16 \\
\hline 2 & Rimbo Data & 669 & 82 & 12,3 & 664 & 58 & 8,73 & 639 & 46 & 7,20 \\
\hline 3 & Dangung-Dangung & 793 & 175 & 22,1 & 780 & 76 & 9,74 & 829 & 66 & 7,96 \\
\hline 4 & Baruah Gunuang & 1.999 & 90 & 4,5 & 1.617 & 149 & 9,21 & 1.691 & 106 & 6,27 \\
\hline 5 & Maek & 1.999 & 90 & 4,5 & 1.617 & 149 & 9,21 & 1.691 & 106 & 6,27 \\
\hline 6 & Banja Laweh & 835 & 128 & 15,3 & 580 & 91 & 15,69 & 659 & 60 & 9,10 \\
\hline 7 & Gunung Malintang & 1.999 & 111 & 5,6 & 1.617 & 149 & 9,21 & 1.691 & 100 & 5,91 \\
\hline 8 & Sialang & 1.722 & 62 & 3,6 & 1.542 & 78 & 5,06 & 1.478 & 66 & 4,47 \\
\hline 9 & Piladang & 1.722 & 62 & 3,6 & 1.542 & 78 & 5,06 & 1.478 & 83 & 5,62 \\
\hline 10 & Halaban & 1.999 & 126 & 6,3 & 1.617 & 149 & 9,21 & 1.691 & 106 & 6,27 \\
\hline 11 & Mungka & 1.722 & 64 & 3,7 & 1.542 & 73 & 4,73 & 1.478 & 83 & 5,62 \\
\hline 12 & Pakan Rabaa & 515 & 127 & 24,7 & 468 & 76 & 16,24 & 453 & 53 & 11,70 \\
\hline 13 & Suliki & 515 & 127 & 24,7 & 468 & 91 & 19,44 & 453 & 53 & 11,70 \\
\hline 14 & Muaro Paiti & 1.722 & 113 & 6,6 & 1.542 & 98 & 6,36 & 1.478 & 66 & 4,47 \\
\hline 15 & Koto Baru & 669 & 127 & 19,0 & 664 & 91 & 13,70 & 410 & 46 & 11,22 \\
\hline 16 & Batu Hampar & 1.068 & 111 & 10,4 & 1.025 & 95 & 9,27 & 999 & 100 & 10,01 \\
\hline 17 & Taram & 1.068 & 128 & 12,0 & 1.025 & 95 & 9,27 & 999 & 100 & 10,01 \\
\hline 18 & Koto tinggi & 793 & 175 & 22,1 & 780 & 76 & 9,74 & 829 & 66 & 7,96 \\
\hline 19 & Situjuah & 835 & 128 & 15,3 & 1.025 & 91 & 8,88 & 999 & 60 & 6,01 \\
\hline 20 & Mungo & 676 & 43 & 6,4 & 323 & 73 & 22,60 & 349 & 40 & 11,46 \\
\hline 21 & Pangkalan & 676 & 50 & 7,4 & 571 & 44 & 7,71 & 481 & 40 & 8,32 \\
\hline \multirow[t]{4}{*}{22} & Tanjung pati & 1.068 & 111 & 10,4 & 1.617 & 95 & 5,88 & 1.691 & 100 & 5,91 \\
\hline & Jumlah & 25.899 & 2.405 & 9,29 & 23.206 & 2.024 & 8,72 & 23.125 & 1.80 & 6,83 \\
\hline & Akurasi & $93,60 \%$ & $91,06 \%$ & $85,24 \%$ & $97,65 \%$ & $97,38 \%$ & $95,09 \%$ & $95,62 \%$ & $94,22 \%$ & $90,17 \%$ \\
\hline & Akurasi Rata-Rata & & & & & $93,73 \%$ & & & & \\
\hline
\end{tabular}
disajikan pada Tabel 2.

Tabel 2. Hasil Percobaan Simulasi Prediksi Tingkat Prevalensi Stunting Tahun 2021

Adapun perhitungan yang dapat dilakukan untuk menentukan akurasinya dari prediksi yang dilakukan adalah dengan cara sebagai berikut :

$$
\text { Tingkat Akurasi }=\frac{\text { nilai terkecil }}{\text { nilai terbesar }} \times 100 \%
$$

Dari Tabel 2 dapat diketahui bahwa tingkat pravelansi stunting yang tertinggi berada pada puskesmas Pakan Rabaa dan puskesmas Suliki sebesar 11,70, sebagai upaya percepatan penanganan Stunting di Kabupaten
Lima Puluh Kota dapat disarankan bahwa sebaiknya dapat diberikan penanganan intensif pada wilayah kerja Puskesmas tersebut. Sedangkan tingkat prevalensi Stunting yang terendah berada pada puskesmas Muaro Paiti dan puskesmas Sialang sebesar 4,47. Sehingga dapat disimpulkan bahwa tingkat pravelensi Stunting Kabupaten Lima Puluh Kota untuk tahun 2021, terprediksi sebesar 6,81 atau turun sebesar 1,91 dari tingkat prevalensi stunting tahun sebelumnya sebesar 8,72 dengan tingkat akurasi rata-rata sebesar 93,73. 


\section{Kesimpulan}

Penerapan metode Monte Carlo dalam prediksi tingkat prevalensi stunting berhasil dilakukan sehingga dapat diprediksi bahwa puskesmas Pakan Rabaa dan puskesmas Suliki memiliki tingkat prevalensi stunting yang tertinggi sehingga memerlukan intevensi dalam menekan angka prevalensi stunting di Kabupaten Lima Puluh Kota.

\section{Daftar Rujukan}

[1]. Muhammad Ridho Nugroho, Rambat Nur Sasongko, Muhammad Kristiawan, 2021, Faktor-faktor yang Mempengaruhi Kejadian Stunting pada Anak Usia Dini di Indonesia, Jurnal Obsesi: Jurnal Pendidikan Anak Usia Dini, Volume 5 Issue 2 Pages 1764-1776, https://doi.org/10.31004/obsesi.v5i2.967

[2]. Meri Anggryni, Wiwi Mardiah, Yanti Hermayanti, Windy Rakhmawati, Gusgus Graha Ramdhanie, Henny Suzana Mediani, 2021, Faktor Pemberian Nutrisi Masa Golden Age dengan Kejadian Stunting pada Balita di Negara Berkembang, Jurnal Obsesi: Jurnal Pendidikan Anak Usia Dini, Volume 5 Issue 2 Pages 1764-1776, DOI: 10.31004/obsesi.v5i2.967

[3]. Traverso L., Mazzoli E , Miller C, Pulighe G. , Perelli, Morese M. M and Branca, (2021), Cost Benefit and Risk Analysis of Low iLUC Bioenergy Production in Europe Using Monte Carlo Simulation, Energies 2021, 14, 1650, https://doi.org/10.3390/en14061650

[4]. Ziad Francis, Sebastien Incerti,, Sara A. Zein, Nathanael Lampe,Carlos A. Guzmanc and Marco Durante, (2021), Monte Carlo Simulation of SARS-CoV-2 Radiation-Induced Inactivation for Vaccine Development, Radiation Research 195, 221-229, DOI: https://doi.org/10.1667/RADE-20-00241.1

[5]. Abrar Hussain, Lihao Yang, Shifeng Mao, Bo Da, Karoly, Tok Esi, Z.J. Ding, (2021), Determination of electron backscattering coefficient of beryllium by a high-precision Monte Carlo simulation, Elsevier Nuclear Materials and Energy 26, 100862, https://doi.org/10.1016/j.nme.2020.100862

[6]. I-Kai Chen, Matthew D.Klimek, and Maxim Perelstein,(2021),Improved neural network Monte Carlo simulation, SciPost, $\quad 10 \quad$ (023) https://doi.org/10.21468/SciPostPhys.10.1.023

[7]. Magdalena Kruza a , David Shaw a , Jacob Shaw b , Nicola Carslaw, (2021), Towards improved models for indoor air chemistry: A Monte Carlo simulation study, Elsevier Atmospheric Environment, 1352-2310, https://doi.org/10.1016/j.atmosenv.2021.118625

[8]. Paper C., Colucci L., and Albino R. D., (2017), Predicting the Unpredictable: Using Monte Carlo Simulation to Predict Project Completion Date Predicting the Unpredictable: Using Monte Carlo Simulation to Predict Project Completion Date, no. October, pp. 0-6, https://doi.org/10.1007/978-3-319-559070

[9]. Santony, J. (2020), Simulasi Penjadwalan Proyek Pembangunan Jembatan Gantung dengan Metode Monte Carlo,
J. Informasi \& Teknologi., vol. 2, no. 1, pp. 30-35, https://doi.org/10.37034/jidt.v2i1.34

[10]. Surat Keputusan Menteri Perencanaan Pembangunan Nasional/ Kepala Badan Perencanaan Pembangunan Nasional, Nomor. 10/M.PPN/HK/02/2021 Tentang Penetapan Perluasan Kabupaten/Kota Lokasi Fokus Intervensi Penurunan Stunting Terintegrasi Tahun 2022 Tanggal 25 Februari 2021.

[11]. Tarek Bouazizi, Mongi Lassoued, Zouhaier Hadhek, (2020), Oil Price Volatility Models during Coronavirus Crisis: Testing with Appropriate Models Using Further Univariate GARCH and Monte Carlo Simulation Models, International Journal of Energy Economics and Policy, 11(1), 281-292, DOI: https://doi.org/10.32479/ijeep.10374

[12]. Abroon Qazi, Abdulrahim Shamayleh, Sameh El-Sayegh, Steven Formaneck, (2020) Prioritizing risks in sustainable construction projects using a risk matrix-based Monte Carlo Simulation approach, Elsevier Science Direct Sustainable Cities and Society journal, 2210-6707, https://doi.org/10.1016/j.scs.2020.102576

[13]. Aminatunisa S., Diarnia M.S.S., Gultom Y., Enjelika M., Mazmur S.P., Evta I., (2019), Penerapan Metode Monte Carlo Untuk Simulasi Sistem Antrian Service Sepeda Motor Berbasis Web, Jurnal Sistem Informasi Ilmu Komputer Prima, Vol. 2 No. 2, Doi : https://doi.org/10.34012/jusikom.v2i2.442

[14]. Geni B. Y., Santony, J., and Sumijan, (2019) Prediksi Pendapatan Terbesar pada Penjualan Produk Cat dengan Menggunakan Metode Monte Carlo, J. Inform. Ekon. Bisnis, vol. 1, no. 4, pp. 15-20, , doi: https://doi.org/10.37034/infeb.v1i4.5

[15]. Santony, J. (2019), Prediksi Pajak Mineral Non Logam dan Batuan dengan Metode Monte Carlo, J. Informasi \& Teknologi., vol. 1, no. 4, pp. 32-37, https://doi.org/ 10.37034 jidt.v1i4.33

[16]. Manurung K. H. and Santony J., (2019), Simulasi Pengadaan Barang menggunakan Metode Monte Carlo, J. Sistim Inf. dan Teknol., vol. 1, no. 3, pp. 7-11, https://doi.org/ 10.35134/jsisfotek.v1i3.3

[17]. Putra D.E., J.Santony., and G. W. Nurcahyo, (2019), Prediksi Pengeluaran Anggaran Operasional Perguruan Tinggi Swasta Dengan Menggunakan Metode Monte Carlo, J. Sistem Informasi Robotik., vol. 4, no. 2, pp. 49-60. https://doi.org/ /jsir.v4i2.50

[18]. Safitri D., Dahdah.S.S., and Andesta.D., (2019), Penerapan Metode Monte Carlo Pada Perencanaan Jumlah Produksi Pestisida, Jurnal Sistem Dan Teknik Industri, vol.1, no.1, pp. 20-43. https://doi.org/10.30587/justicb.v1i1.2043

[19]. Yicheng Zhou, Zhenzhou Lu, Kai Cheng, Wanying Yun, (2019), A Bayesian Monte Carlo-based method for efficient computation of global sensitivity indices, Elsevier Mechanical Systems and Signal Processing, 498-516, https://doi.org/10.1016/j.ymssp.2018.08.015

[20]. Wijaya F. S., and Sulistio.H., (2019), Penerapan Metode Monte Carlo Pada Penjadwalan Proyek Serpong Garden Apartment, Jurnal Mitra Teknik Sipil, Vol. 2, No.3, 2019: pp. 189-198. https://doi.org/10.24912/jmts.v2i3.5828 